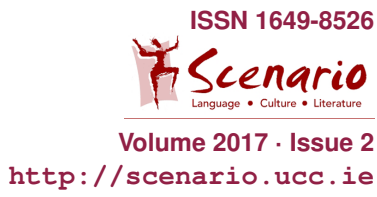

TaT - Texts around Theatre - TaT

\title{
A Passion for the Arts
}

\author{
An extract from 'Why Can't Everything Just Stay the Same?' by \\ Stefanie Preissner
}

\section{Fionn Woodhouse}

I first met Stefanie Preissner when she signed up as a volunteer leader with Lightbulb Youth Theatre in Mallow, Cork. Having recently begun a BA in Drama and Theatre Studies in University College Cork, Stefanie had the interest in the work that allowed her to quickly become integral to Lightbulb, facilitating workshops and directing performances. We established a good working relationship, devising, writing and directing within the youth theatre before forming our own theatre company, 'With an F Productions', allowing us to take on different projects. Stefanie's move to Dublin, after graduating from Drama and Theatre Studies, allowed her to develop her playwriting skills leading to the writing of 'Solpadine is My Boyfriend'. This play was subsequently produced by the company enjoying a sell-out run in Dublin before touring internationally to Bucharest, Edinburgh and Australia, and - as a radio play - becoming RTE's most downloaded podcast. Stefanie has gone on to write for RTE, with the successful series 'Can't Cope, Won't Cope' now in its second season and is also writing for Channel 4 in the UK and First Look Media in the US. Last year, I hosted Stefanie in the renamed 'Department of Theatre' to talk with students and staff about her experiences as a writer and how her time in UCC has helped shape her work.

In this extract from her autobiographical book, Why Can't Everything Just Stay the Same? Stefanie reflects on what first attracted her to theatre and the passion of professionals who work in the industry.

I started acting when I was sixteen. Up until then, I had always thought that drama classes were for people who were bad at sport or who had a speech impediment. I wasn't wrong about the sports. When I got my first starring role in our transition-year opera The Mikado, and experienced the teamwork involved in putting on a show, I was hooked. All of the community and togetherness that solo swimming couldn't give me, and all the years of playing Super Nintendo one-player games as an only child, were delivered by the experience of theatre.

I guess I was lucky that I happened to be quite good at something I loved so much. I joined a youth theatre in Cork after transition year and thrived in the atmosphere created by Geraldine, the director. She was hands-off enough to 
make us feel like we were free to discover who we were, but very professional and demanding of our commitment to her shows. 'Commit or Quit' was a speech Geraldine used to give to people who were showing up late for rehearsals. I loved her and her rules so much.

I found people who worked professionally in the theatre industry attractive because they seemed to be running on passion. They certainly weren't doing it for the money. We live in a society that grossly undervalues the arts and so the people who are involved and successful are necessarily driven and ambitious and passionate about what they do. Geraldine taught me that when people are primed to dismiss you for being a non-essential part of society, you must never give them supportive evidence. People expect artists to be late, to be scatty, to be over-emotional and unbusinesslike. 'You must show up early, and be more professional and competent than your non-artist counterpart because that is the only way you will serve the arts and the generations of artists that have gone before you.'

I was fortunate to meet brilliant practitioners early in my acting career, before it even was even a career. When I was eighteen, I worked with another director who refused to lower his demands on his actors because they were young. He said that youth was not an excuse for amateurism, and explained that he would be running our rehearsals and the subsequent production exactly as he would if it had been produced at the Abbey theatre. His argument was that he was a professional and to expect anything less than the best from us was a slight on his reputation if nothing else.

\section{Bibliography}

Stefanie Preissner (2017): Why Can't Everything Just Stay the Same? And other things I shout when I can't cope. Dublin: Hachette Books, 84-85. 